\title{
Chromatic light effects and physiological modeling of absorption properties of Heterocapsa pygmaea (= Glenodinium sp.)
}

\author{
Norman B. Nelson, Barbara B. Prézelin \\ Department of Biological Sciences and Marine Science Institute, University of California, Santa Barbara, California 93106, USA
}

\begin{abstract}
Growth and absorption properties of the marine dinoflagellate Heterocapsa pygmaea (also known as Glenodinium sp.) were defined for batch cultures of populations grown in blue and green light. Log-phase cells exhibited variations in growth rate, cell volume, pigmentation, chlorophyllspecific absorption, absorption cross-sections for photosynthesis and cellular packaging effects that were dependent upon spectral growth irradiances ( 5 to $150 \mu \mathrm{Ein} \mathrm{m}^{-2} \mathrm{~s}^{-1}$ ). By combining knowledge of (1) cellular pigmentation, (2) the distribution of specific pigments into discrete light-harvesting components, and (3) newly-derived pigment-specific absorption coefficients for the major pigment-protein complexes in dinoflagellates, it was possible to reconstruct the photosynthetic absorption properties of the dinoflagellate. The degree of fit between measured and reconstructed absorption spectra varied as a function of spectral growth irradiance. In most instances, the majority of the discrepancy was attributable to a wavelength-dependent package effect, which ranged from 1 to $30 \%$ depending upon growth irradiance control of cell pigmentation and cell volume. Preliminary results contribute to the development of a model which uses field measurements of pigmentation and cell characteristics to monitor the presence, distribution, and bio-optical properties of red-tide dinoflagellates.
\end{abstract}

\section{INTRODUCTION}

Populations of photosynthetic dinoflagellates occur naturally as endosymbionts of marine invertebrates, as red tides, as daily vertical migrants within the euphotic zone, and as physically entrained successional components of frontal boundaries and upwelling plumes (Taylor 1986). The reddish discoloration that occurs wherever these photosynthetic dinoflagellates aggregate in high number is caused by their unique photosynthetic pigmentation, more specifically the watersoluble light-harvesting perdinin-chlorophyll-(chl)aprotein (PCP) complexes, and chl a-protein complexes containing chl $c_{2}$ (Prézelin 1976). As such, the presence of high dinoflagellate abundances in diverse coastal marine environments should predictably alter the inherent and apparent optical properties of the water column, including spectral absorption, scattering, attenuation and reflectance (Dubinsky \& Berman 1979, Kirk 1983, Balch et al. 1989). Laboratory studies have shown these unique light-harvesting components (LHCs) to be photoregulated, with rates and magnitudes of pigment turnover being dependent on the physiological growth state of the cells (cf. Prézelin 1976, Roman et al. 1988). As a result of physiologically regulated photoadaptive responses, a light-dependent variability in dinoflagellate absorption signatures in situ should be derivable from knowledge of pigmentation and cell dimensions.

The present study quantifies the effects of spectral growth irradiance, pigmentation and cell volume on estimates of cell absorption, absorption cross-section, and cellular package effect of the dinoflagellate Heterocapsa pygmaea (also known as Glenodinium sp.). In doing so, an approach is developed and tested which enables reconstruction of in situ whole cell absorbance properties of photosynthetic dinoflagellates from knowledge of cell pigmentation, distribution of specific pigments within discrete light-absorbing components, and newly-derived pigment-specific absorption coefficients for the major pigment-protein complexes in dinoflagellates. These spectral reconstruction techniques will be used in future studies for bio-optical modeling of primary production rates of dinoflagellates (Bidigare et al. 1987, Smith et al. 1989) 


\section{MATERIALS AND METHODS}

Growth conditions. Glenodinium sp., L. Provasoli, M. Bernard isolate; UCSB code 5M29, also known as Heterocapsa pygmaea (Loeblich et al. 1981), was grown in unialgal batch culture in $500 \mathrm{ml}$ acid-washed Pyrex Erlenmeyer flasks containing $300 \mathrm{ml}$ of $\mathrm{f} / 2$ medium (Guillard \& Ryther 1962). A recirculating water bath provided cooling water to maintain cultures at $18 \pm 1^{\circ} \mathrm{C}$. The culture flasks were fitted with opaque cones to allow only illumination directed from below to reach the flasks. Constant illumination was provided by GTE FCL $500 \mathrm{~W}$ tungsten-halogen bulbs placed beneath a Plexiglas tank supporting the culture flasks. Spectral output of the light source was measured at $5 \mathrm{~nm}$ intervals over the visible spectrum using a $50 \mathrm{~cm}$ Ebert monochromator set (Jarrel-Ash \#82-440) configured to reduce scattering loss to $0.0001 \%$. A Li-Cor LI-185B 400-700 nm quantum collector placed at the exit slit of the monochromator served as the detector. Resulting spectra were corrected with published data for the variable spectral sensitivity of the Li-Cor sensor (Lambda Instrument Co.). To generate the desired spectral irradiances (Fig. 1), the incident light was filtered with a $1 \mathrm{~cm}$ cell of $0.5 \mathrm{M} \mathrm{CuSO}_{4}$ covered with one layer of either blue (Lee \#120) or green (Lee \#124) polyester 'photographic gel' filters. Transmittance spectra of the $\mathrm{CuSO}_{4}$-filter combinations were made with an Aminco DW-2a scanning spectrophotometer, and multiplied by the output spectra of the lamps as

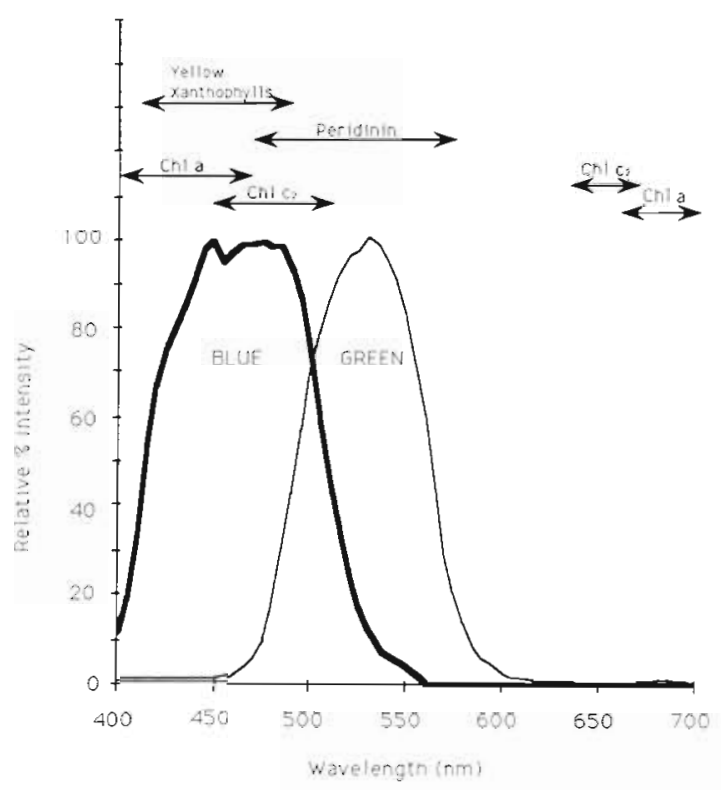

Fig. 1. Spectral output for blue and green light growth irradiances. Wavelength ranges for light absorption by major pigments present in Heterocapsa pygmaea are indicated by horizontal bars and include chl $a$, chl $c_{2}$, peridinin, and yellow xanthophylls measured above. Varying irradiances, ranging from 5 to $150 \mu$ Ein $\mathrm{m}^{-2} \mathrm{~s}^{-1}$, were achieved by placing black mesh neutral density screens between the flasks and the light source.

Since the past history of inocula affects growth rate and cell composition of batch populations, care was taken to keep cultures in mid-exponential phase of growth by serial dilution for at least 3 generations and until pigment concentrations and growth rates reached steady-state values at each spectral growth irradiance. Growth rates were calculated from changes in cell densities monitored daily using an American Optical hemacytometer (Guillard 1973). Individual cells were sized using an ocular micrometer. Cell volumes were estimated from mean cell dimensions, assuming cylindrical cell shape (Kovala \& Larrence 1966).

Whole-cell absorbance spectra. Heterocapsa pygmaea cells were concentrated by centrifugation and resuspended in a small volume of supernatant. Absorption spectra of the concentrated samples were measured in an Aminco DW-2a spectrophotometer using the opal glass technique (Shibata et al. 1954, Shibata 1959, Morel \& Bricaud 1981, Bricaud \& Morel 1983, Boucher et al. unpubl.), with recovered supernatant serving as the blank. The instrument was equipped with a single opal glass between the sample compartment and the photomultiplier, and used a beam scrambler' to eliminate the variable response of different areas of the photomultiplier tube. Serial dilutions of the concentrated suspension were measured to confirm the linearity of absorbance with dilution (Sathyendranath et al. 1987). These control measurements demonstrated the applicability of Beer's law and the absence of multiple scattering (Kirk 1983). Minimum transmittance of the samples was $>95 \%$ after dilution. Average absorption cross-section $\overline{\alpha A}\left(\mu \mathrm{m}^{2}\right.$ cell $\left.{ }^{-1}\right)$, where $\alpha$ is the projected area of the cell and $A$ is the particle absorptance, was calculated for a $1 \mathrm{~cm}$ pathlength cell by the formula:

$$
\overline{\alpha A}=\frac{2.303 \mathrm{D}}{\Pi}
$$

where $D=$ optical density of the suspension; $\mathrm{n}=$ number of cells in $1 \mathrm{~cm}^{3}$; and $2.303=$ a conversion factor from $\log _{10}$ to $\log _{e}$ units (Kirk 1983). Photosynthetically absorbed radiation [PHAR, $\mu$ Ein s $^{-1}\left(\mathrm{mg} \mathrm{chl} \mathrm{a}^{-1}\right.$ ] was calculated on a per-chl basis as:

$$
\text { PHAR }=\int_{400}^{700} \operatorname{PAR}(\lambda) \mathrm{a}^{*}(\lambda) \mathrm{d} \lambda
$$

where $\operatorname{PAR}(\lambda)$ is spectral growth irradiance $\left(\mu \mathrm{Ein} \mathrm{m}^{-2}\right.$ $\mathrm{s}^{-1} \mathrm{~nm}^{-1}$ ) and $\mathrm{a}^{*}(\lambda)$ is the chl-specific absorption spectrum $\left[\mathrm{m}^{2}(\mathrm{mg} \mathrm{chl} \mathrm{a})^{-1}\right]$. Cell-specific PHAR (uEin cell ${ }^{-1}$ $\left.s^{-1}\right)$ was calculated as the product of chl-specific PHAR (Eq. 2) and the cellular chl a content (mg chl a cell ${ }^{-1}$ ). 
Pigmentation. Whole-cell samples $(50$ to $100 \mathrm{ml})$ were gently filtered $(<125 \mathrm{~mm} \mathrm{Hg}$ ) onto $25 \mathrm{~mm}$ Nuclepore membrane filters ( $1 \mu \mathrm{m}$ pore) and frozen for $24 \mathrm{~h}$ prior to extraction in $90 \%$ acetone. Chl a, chl c, peridinin, and combined yellow xanthophylls including diadinoxanthin and dinoxanthin were separated and quantified using reverse-phase HPLC (Mantoura \& Llewellyn 1981). A Beckman Ultrasphere RP-18 column was used in combination with a Waters model \#441 HPLC apparatus equipped with a variable absorbance detector, set to $440 \mathrm{~nm}$. A 2-step solvent program was employed consisting of a linear ramp from $100 \%$ solvent $\mathrm{A}\left(80: 10: 10 \mathrm{MeOH}: \mathrm{H}_{2} \mathrm{O}\right.$ : Ion Pairing Agent) to $100 \%$ solvent $\mathrm{B}(80: 20 \mathrm{MeOH}$ : acetone) over a period of $10 \mathrm{~min}$, followed by an isocratic hold for 12 min. Instrument response factors (peak area: weight pigment) and retention times were determined by injecting pigment standards extracted and purified from Heterocapsa pygmaea by repetitive TLC (Jeffrey 1981), Pigment standards were quantified spectrophotometrically using published extinction coefficients (Prézelin 1976 for peridinin; Mantoura \& Llewellyn 1981 for other pigments).

Reconstructed absorption spectra. The approach to reconstruction of dinoflagellate absorption spectra was based on that first developed for diatoms (Bidigare et al. 1987) and recently extended to cyanobacteria (Bidigare et al. 1989). Absorption spectra $[a(\lambda)]$ were recon-

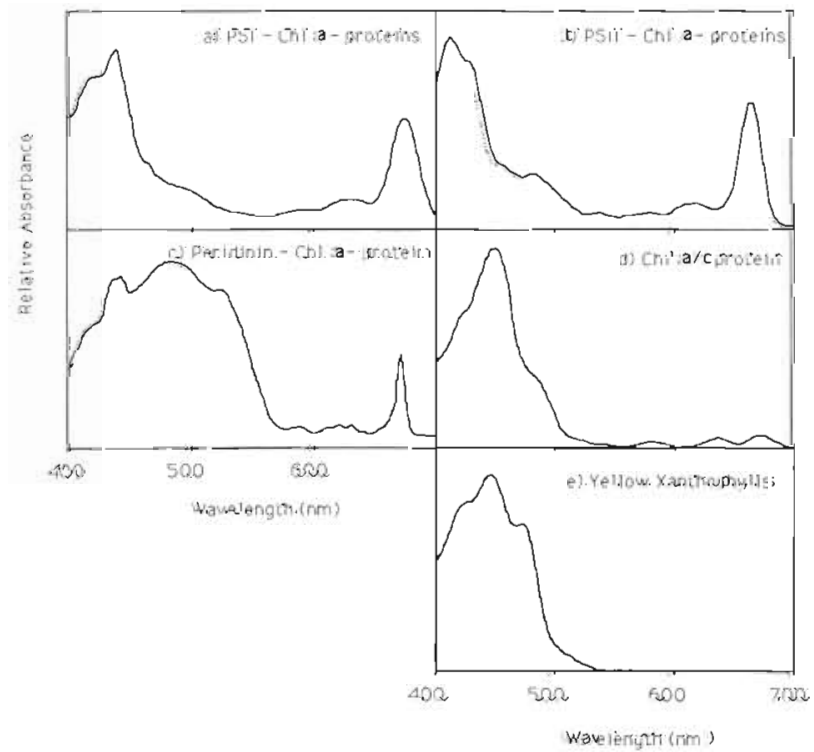

Fig. 2. Chl-specific absorption spectra of the major lightharvesting pigment-protein complexes of dinoflagellates. (a) P700-chl a-containing protein complexes (Prézelin \& Alberte 1978); (b) PSII-chl a-protein complexes (McTavish et al. 1989); (c) peridinin-chl a-protein complexes (PCP) (Prézelin 1976); (d) chl a-chl $c_{2}$-protein complexes (Boczar et al. 1980); (e) nonphotosynthetically active xanthophylls in methanol (this study) structed by summing the products of the concentrations $\left(c_{1}\right)$ of the dinoflagellate pigment-protein complexes present with their respective weight-specific absorption coefficient spectra $\left[a^{\circ}{ }_{1}(\lambda)\right]$, such that:

$$
\mathrm{a}(\lambda)=\sum \mathrm{a}_{1}{ }_{1}(\lambda) \quad \mathrm{c}_{i}
$$

In contrast to previous work, dinoflagellate reconstructed spectra were based on knowledge of the pigment distribution within the chromophores of discrete pigment-protein complexes (Prézelin \& Boczar 1986), including the reaction center core complexes of Photosystem I (PS I) (Fig. 2a; Prézelin \& Alberte 1978), Photosystem II (PS II) (Fig. 2b; McTavish et al. 1989), light-harvesting PCP at $77 \mathrm{~K}$ (Fig. 2c; Prézelin \& Boczar 1981), and chl a-chl $c_{2}$-protein complexes (Fig. 2d; Boczar et al. 1980). Since the distribution of yellow xanthophylls within dinoflagellate cells is incompletely defined (Prézelin \& Boczar 1981), the absorbance spectrum of yellow xanthophylls in $90 \%$ acetone (Fig. 2e) was measured from pigments purified by TLC (see above). Absorption spectra for complexes containing $\mathrm{chl} \mathrm{a}$ were normalized to $0.02 \mathrm{~m}^{2}$ ( $\left.\mathrm{mg} \mathrm{chl} \mathrm{a}\right)^{-1}$ at the red chl a absorption peak. The $77 \mathrm{~K}$ absorbance spectrum of PCP has been identified as a more accurate reflection of in vivo PCP absorption than the room temperature spectrum, where the peridinin dimer absorbs at $480 \mathrm{~nm}$ and the carotenoid shoulder at $530 \mathrm{~nm}$ is less pronounced (Prézelin et al. 1976).

Utilizing the chromophore composition of the discrete pigment proteins (Prézelin \& Boczar 1980) and measured pigment content, the concentration of pigment-protein complexes $\left(c_{l}\right)$ could be estimated. All peridinin in Heterocapsa pygmaea appeans to be within PCP (Prezelin \& Boczar 1980), where the molar ratio of peridinin to chl $a$ is $4: 1$ and no other pigments are present (Prézelin 1976. Song et al. 1976). Therefore all peridinin, and chl a equal to $1 / 4$ the cell content of peridinin, can be assigned to PCP complexes. Similarly, the number of $\mathrm{chl}$ a-chl $c_{2}$ complexes and the number of chl a molecules assigned to them was calculated to be $1 / 5$ of the number of chl $c_{2}$ molecules in the cell, given the 5:1 chl $c_{2}$ : a molar ratio of the protein (Boczar et al. 1980). The remaining chl $a$, after assigning chl a to PCP and subtracting the chl a-chl $c_{2}$ complex, was assigned equally to the PS I and PS II reaction center complexes. Equal numbers of PS I and PS II reaction centers are consistent with dinoflagellate photoadaptive strategies (Prézelin 1987).

Package effect calculations. Absorption spectra of intact pigmented cells are known to be lower in magnitude than those of sonicated cells or extracted pigments (Kirk 1983, Berner et al. 1989). The wavelengthdependent fractional reduction of specific absorption due to the package effect was calculated for reconstructed spectra by reversing the method described for 
calculating 'unpackaged' absorption spectra (Morel \& Bricaud 1981). The measured quantities a ${ }^{*}{ }_{\text {sol }}(\lambda)$ [reconstructed absorption spectrum; $\left.\mathrm{m}^{2}(\mathrm{mg} \mathrm{chl} a)^{-1}\right]$, and $\mathrm{C}_{1}$ (intracellular chl a content per unit cell volume; mg $\left.\mathrm{m}^{-3}\right)$ were used to determine $\mathrm{a}_{\mathrm{cm}}(\lambda)$, the cell material absorption coefficient, from the equation:

$$
\mathrm{a}_{{ }_{\text {sol }}(\lambda)}=\frac{\mathrm{a}_{\mathrm{rm}}(\lambda)}{\mathrm{C}_{\mathrm{i}}}
$$

The chl-specific absorption coefficient $a^{\bullet}(\lambda)$ for the cell suspension can then be calculated as:

$$
a \cdot(\lambda)=a \cdot{ }^{*}{ }_{s o l}(\lambda) \cdot \frac{3}{2} \frac{Q_{a}(\lambda)}{a_{c m}(\lambda) d}
$$

where $d=$ diameter of a sphere of volume equivalent to the cell volume; $Q_{a}(\lambda)=$ absorption efficiency or fractional light absorption of the cell (Bricaud \& Morel 1983, Iturriaga et al. 1988); $Q_{a}=$ a function of the dimensionless property $\mathrm{a}_{\mathrm{cm}} \mathrm{d}$ or rho prime, $\rho^{\prime}$, and is given by

$$
Q_{a}=1+\frac{2 e^{-\rho^{\prime}}}{\rho^{\prime}}+2 \frac{e^{-\rho^{\prime}}-1}{\rho^{\prime} 2}
$$

The ratio of $\mathrm{a}^{*}$ to $\mathrm{a}{ }^{\text {sol }}$ (referred to as $\mathrm{Q}^{*}$ a in Morel \& Bricaud 1981, and F in Sathyendranath et al. 1987) is a measure of the package effect. As $Q^{*}$ a decreases, the flattening of the absorption peaks becomes stronger, signifying increased package effect.

This method for approximating suspension absorption coefficients assumes spherical shape and homogeneous cell composition. The spherical approximation was found to be accurate for cells for varying size and pigmentation from different phyla (Morel \& Bricaud 1981, Sathyendranath et al. 1987, Bricaud et al. 1988), so the error associated with the spheroidal shape and multiple chloroplasts of Heterocapsa pygmaea should be small. Where the suspension chl-specific absorption spectrum is known, $Q^{*}{ }_{a}(\lambda)$ values were also estimated from measured spectra according to the methods of Morel \& Bricaud (1981).

\section{RESULTS}

\section{Growth rate and cell volume}

Maximum rates of Heterocapsa pygmaea cell division were independent of light quality (Fig. 3) and were essentially the same as that determined earlier for cultured white light populations of the same H. pygmaea clone (Prézelin 1976). Light-saturated cell division rate for blue and green light quality treatments averaged 0.7 divisions $\mathrm{d}^{-1}$. However, the minimum light requirements for initiating cell division and for obtaining maximal growth rates differed between cells grown in blue and green light. At the lowest irradian-

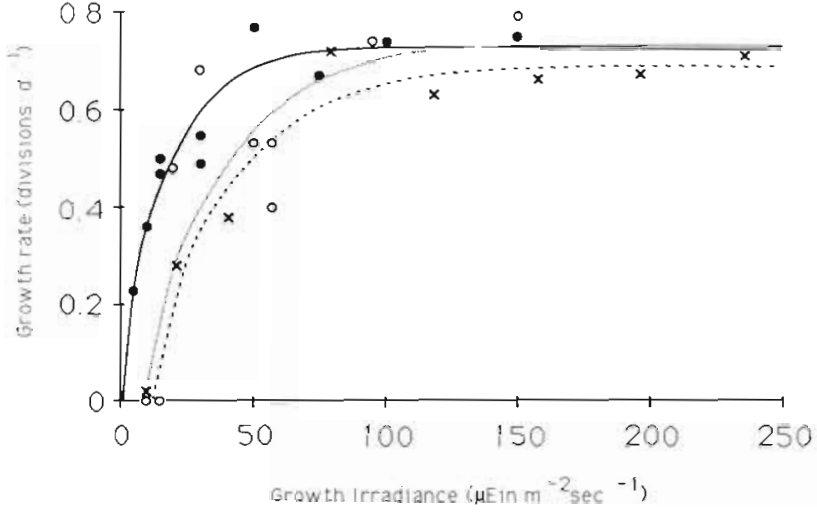

Fig. 3. Heterocapsa pygmaea. Effect of different spectral irradiances of blue ( $\bullet$, solid line) and green growth illumination (o, gray line) on growth. Results are compared with white fluorescent light data ( $\mathrm{x}$, dashed line) from Prézelin (1976)

ces $\left(5 \mu\right.$ Ein $\left.\mathrm{m}^{-2} \mathrm{~s}^{-1}\right)$, blue light grown cells had growth rates equal to $1 / 3$ the maximal rate, and light-saturated growth rates were achieved at $40 \mu$ Ein $\mathrm{m}^{-2} \mathrm{~s}^{-1}$. Neither green nor white light grown cells were capable of growth below about $15 \mu$ Ein $\mathrm{m}^{-2} \mathrm{~s}^{-1}$ and both required $>80 \mu \operatorname{Ein} \mathrm{m}^{-2} \mathrm{~s}^{-1}$ to achieve light-saturated growth rates.

Cell volumes varied 4 -fold over the range of growth irradiances, covarying with rates of cell division (Fig. 4). In white light studies, measurements of packed cell volume did not vary with growth irradiance (Prézelin 1976).

\section{Pigmentation}

The pigment content of Heterocapsa pygmaea changed markedly with changes in growth irradiance and light quality (Fig. 5). Chl a was the most abundant pigment in both blue (Fig. 5a) and green (Fig. 5b) light cells, regardless of growth irradiance. The second most abundant pigment was the red xanthophyll peridinin, followed by chl $c$ and combined yellow xanthophylls.

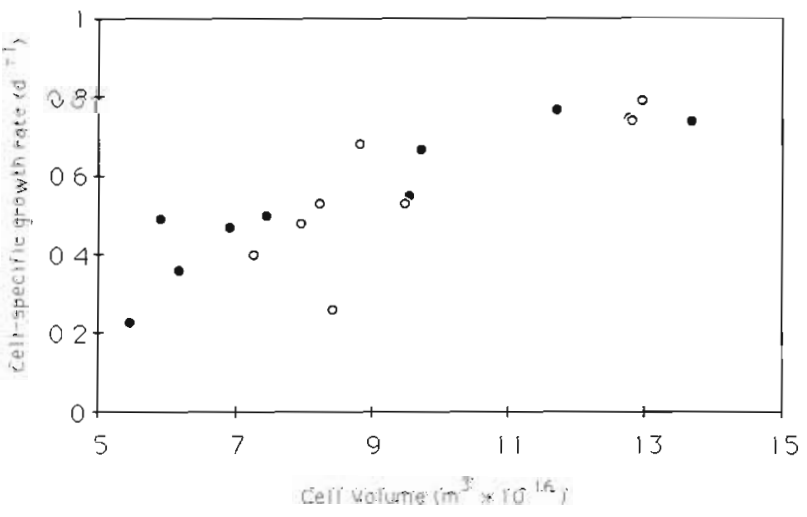

Fig. 4. Heterocapsa pygmaea Relationship between cellspecific growth rate $\left(\mathrm{d}^{-1}\right)$ and cell volume $\left(\mathrm{m}^{3} \times 10^{-16}\right)$ for blue light $(\bullet)$ and green light $(0)$ grown cultures 
This pigmentation pattern contrasted strikingly with white light cells, previously shown (Prézelin 1976; Fig. 5c) to routinely contain peridinin at the same cellular level as the blue and green grown cells, followed closely by nearly equivalent amounts of chl a and chl $c$ and minor amounts of pooled yellow xanthophylls. Recent experiments (unpubl.) have shown white light grown Heterocapsa pygmaea to have pigment ratios similar to those reported by Prézelin (1976) at high and low growth irradiances, suggesting that the difference between white and colored light grown cells is not due to a change in the properties of the strain over time in culture.

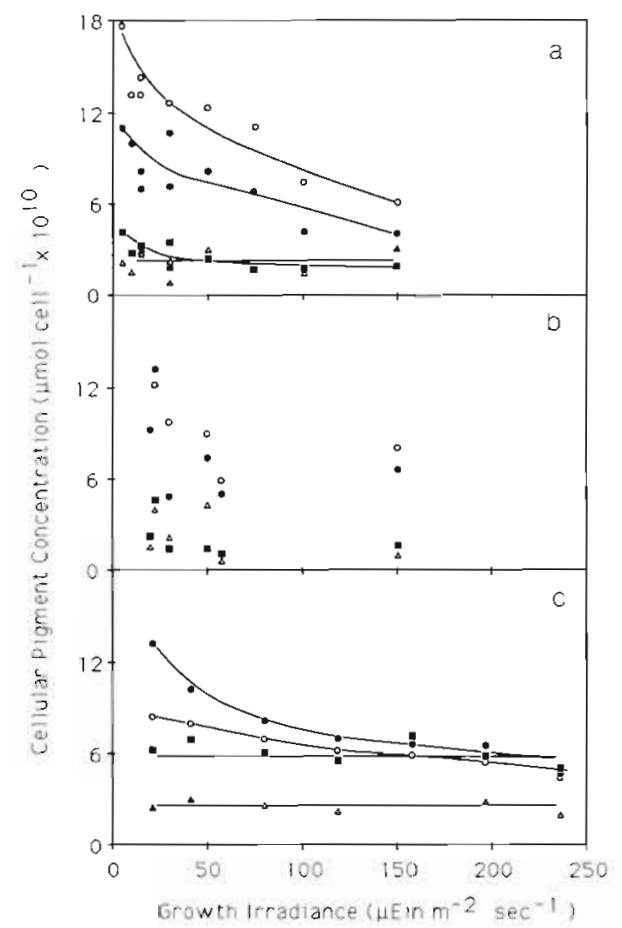

Fig. 5. Heterocapsa pygmaea. Effect of growth irradiance on cellular pigment content $\left(\mu \mathrm{mol} \mathrm{cell}^{-1} \times 10^{-10}\right)$ in (a) blue light and (b) green light grown cultures, compared with (c) white light data of Prézelin (1976). Pigment symbols are: (0) chl a; (•) peridinin; ( $(\mathbf{)})$ chl $c_{2} ;(\Delta)$ combined yellow xanthophylls

\section{Whole cell absorption}

The variability of Heterocapsa pygmaea cell pigmentation with respect to light intensity and quality resulted in variations in chl-specific absorption spectra (Fig. 6). The variations can be summarized by examining chl-specific absorption coefficients at 671 and $440 \mathrm{~nm}$ for blue and green light grown cells (Fig. 7). At growth-limiting irradiances, chl-specific coefficients for both blue and green light cells appeared to decline by as much as 2 -fold. This decline in chl-specific absorption coefficients could be attributed to differences in cellular chl a content (Fig. 8). As a result, chl-specific

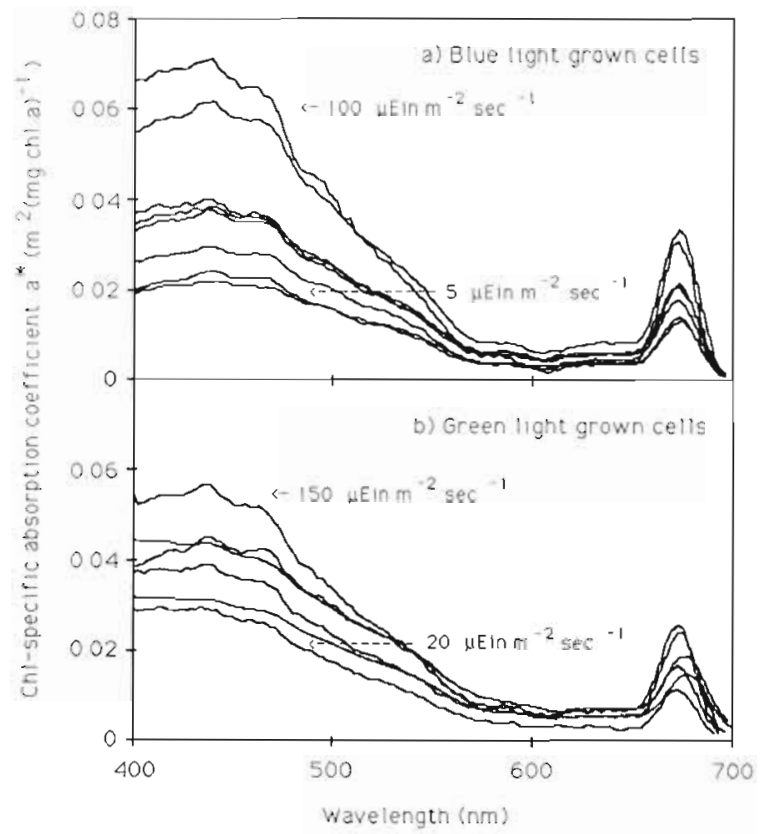

Fig. 6. Heterocapsa pygmaea. Variability in chl-specific absorption coefficient spectra $\left[\mathrm{m}^{2}(\mathrm{mg} \mathrm{chl} \mathrm{a})^{-1}\right]$ with growth irradiance for (a) blue and (b) green light grown cells

absorption coefficients were negatively correlated with cellular levels of chl a in a relationship that appeared independent of the spectral distribution of the growth light field.

Estimates of the average absorption cross-section for $671 \mathrm{~nm}$ appeared to be constant and independent of either cell chl concentrations or the spectral distribu-

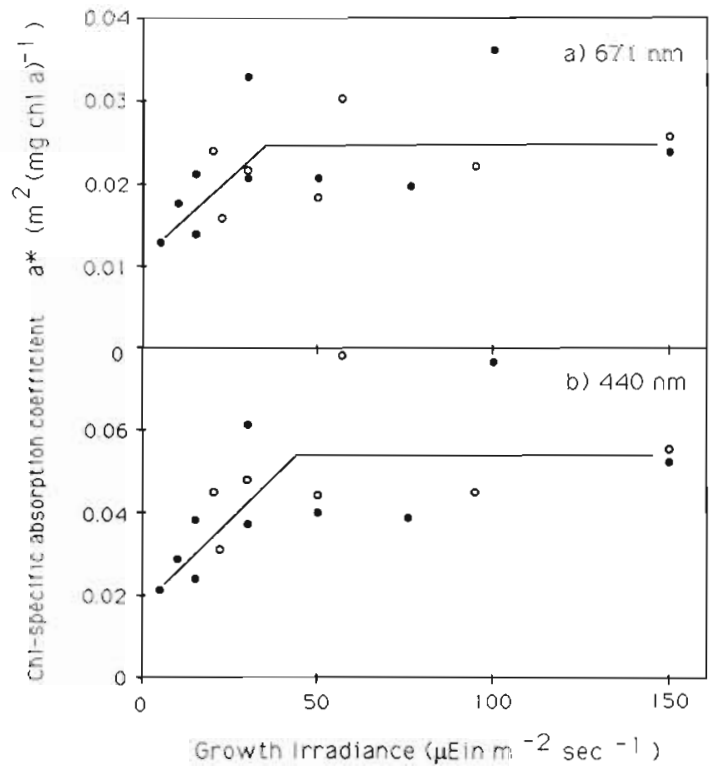

Fig. 7. Heterocapsa pygmaea. Effect of growth irradiance on chl-specific absorption coefficient $\mathrm{a}^{*}\left[\mathrm{~m}^{2}(\mathrm{mg} \mathrm{chl} \mathrm{a})^{-1}\right]$ at (a) $671 \mathrm{~nm}$ and (b) $440 \mathrm{~nm}$ for blue light ( $\bullet$ ) and green light (o) grown cell 
tion of growth $\overline{\alpha A}(671 \mathrm{~nm})$ was calculated to be $8.4 \pm$ $2.4 \mathrm{~cm}^{2}(\mathrm{~m}=13)$. Similarly, while estimates at $440 \mathrm{~nm}$ were more variable, they did appear independent of total cell pigmentation contributing to absorption cross section at this waveband. For blue and green light cells combined, $\overline{\alpha A}(440 \mathrm{~nm})$ was calculated to be $16.0 \pm$ $5.5 \mu^{2}$. Cellular absorption cross section at $671 \mathrm{~nm}$ seems to be maintained constant over a wide range of cellular chl-specific absorption changes, with blue light values slightly higher $(9.1 \pm 1.9, \mathrm{n}=10)$ than those estimated for green light cells $(7.4 \pm 2.5, \mathrm{n}=7)$.

Due to the small variations in average absorption cross-section measurements, both blue and green grown cells exhibit linear relationships between available (PAR) and harvested (PHAR) quanta (Fig. 9). The slope of the relationship for blue cells was a factor of 1.75 greater than that of the green cells, largely due to the coincidence of the blue spectral light field (Fig. 1) with the major blue absorption band in Heterocapsa pygmaea (Fig. 6).

\section{Package effect}

The magnitude of the package effect estimated from measured absorption spectra varied as a function of $C_{i}$, the intracellular chi a concentration (Fig. 10). Values of $Q{ }^{*}{ }_{a}$ at $671 \mathrm{~nm}$ (Fig. 10a) decreased with increasing $C_{i}$, with no significant differences between blue and green

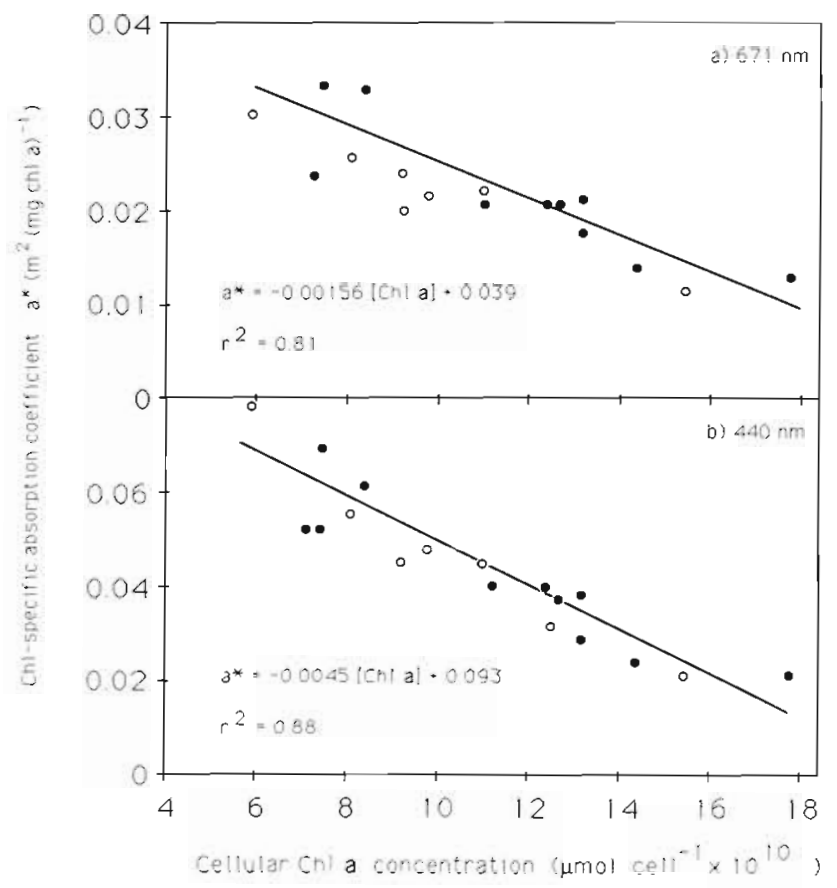

Fig. 8. Heterocapsa pygmaea. Least-squares linear regression relationship between cellular chl a content (umol cell ${ }^{-1} \times$ $10^{-10}$ ) and chl-specific absorption coefficient $a^{*}\left[\mathrm{~m}^{2}\right.$ ( $\mathrm{mg} \mathrm{chl}$ a) ${ }^{-1}$ at (a) $671 \mathrm{~nm}$, and (b) $440 \mathrm{~nm}$ for blue light (•) and green light (o) grown cultures light grown cells. Package effect showed little significant relationship to $C_{1}$ at $440 \mathrm{~nm}$ (Fig. 10b) presumably due to the variable influence of accessory pigments on cell material specific absorption in the blue region of the visible spectrum.

\section{Reconstructed absorption spectra}

Representative measured absorption spectra are compared with the corresponding results of the reconstruction model in Figs. 11 and 12. Samples were chosen to represent cases where (a) growth rates and cell volumes were light-limited and cellular pigmentation was maximal (Figs. $11 \mathrm{a}$ and 12a); (b) growth rates and cell volumes were maximal while cell pigmentation was moderate (Figs. $11 \mathrm{~b}$ and $12 \mathrm{~b}$ ); and (c) growth rates and cell volumes were maximal while cell pigmentation was minimal (Figs. $11 \mathrm{c}$ and 12c). Spectral reconstructions of cells grown under blue light at $5 \mu$ Ein $\mathrm{m}^{-2}$ $\mathrm{s}^{-1}$ (Fig. 11a) overestimated chl-specific absorbance in the 400 to $450 \mathrm{~nm}$ region by up to a factor of 2 . Application of the package effect algorithm reduced this overestimation by $50 \%$. For blue light grown cells grown at $50 \mu$ Ein $\mathrm{m}^{-2} \mathrm{~s}^{-1}$, the reconstructed spectrum where the package effect was considered (Fig. 11b) yielded close agreement with the measured spectrum in the 400 to $450 \mathrm{~nm}$ and 600 to $700 \mathrm{~nm}$ bands, with a slight underestimation of absorbance in the 450 to $600 \mathrm{~nm}$ band. Reconstructed spectra for the $100 \mu$ Ein $\mathrm{m}^{-2} \mathrm{~s}^{-1}$ cells underestimated measured chl-specific absorbance across the entire visible spectrum. For the $20 \mu$ Ein $\mathrm{m}^{-2} \mathrm{~s}^{-1}$ green light cells, (Fig. 12a), the correspondence between the measured and reconstructed spectra were similar to those described for the blue light cells at $50 \mu \operatorname{Ein} \mathrm{m}^{-2} \mathrm{~s}^{-1}$. For green light cells at 50 $\mu$ Ein $\mathrm{m}^{-2} \mathrm{~s}^{-1}$ (Fig. 12b), there was close agreement with the measured spectrum in the 600 to $700 \mathrm{~nm}$ region, but variable underestimation from 400 to $600 \mathrm{~nm}$. Underestimation of specific absorption across most of the spectrum also occurred in green light cells at higher irradiances (Fig. 12c), with close agreement only above $650 \mathrm{~nm}$. In both blue and green high light cases the package effect was small, so the application of the package effect algorithm had minimal impact on the underestimation.

\section{DISCUSSION}

Cell division rate, volume, and pigment concentration in Heterocapsa pygmaea varied as a function of growth irradiance and quality Green and white light grown cells were found to have a higher minimum quantum irradiance requirement for growth than blue light cells, as well as a higher saturation intensity for 


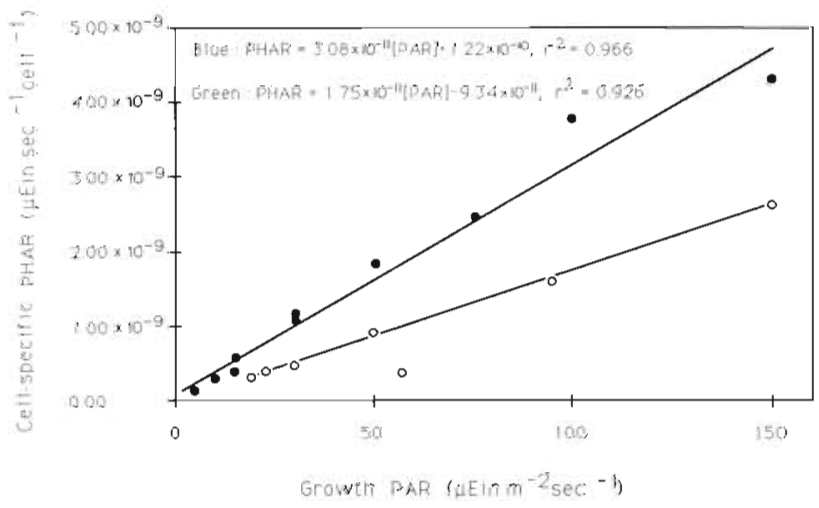

Fig. 9. Heterocapsa pygmaea. Relationship between total spectral growth irradiance (PAR, 400 to $700 \mathrm{~nm}$ ) and cellspecific absorbed quanta (PHAR, 400 to $700 \mathrm{~nm}$ ) for blue light $(\bullet)$ and green light $(0)$ cultures

growth rate. A possible mechanism for this difference lies in the variable harvested light energy between colored light treatments with the same total PAR irradiance (Fig. 9). Lower PHAR for a given green light PAR as opposed to the same blue light PAR can explain the differences in minimum growth irradiance requirement and growth saturation irradiance, but is not sufficient to account for the chromatic variations in pigmentation. White light cells differ in pigmentation from blue and green light cultures which have much higher chl a:peridinin ratios (Fig. 5). This discrepancy may suggest red-light induced suppression of chl a accumulation in H. pygmaea. This study was not designed to provide a critical test of this hypothesis; however, ongoing research concerning the genetic bases of pigment-protein turnover regulation in dinoflagellates (Roman et al. 1988) may provide an answer to this question.

Heterocapsa pygmaea chl-specific absorbance was found to vary directly with growth irradiance (Fig. 7), and inversely with the intracellular chl a content, while being independent of spectral light quality (Fig. 8). Some variation in absorption is attributable to the package effect (Fig. 10), and to other non-pigment factors such as internal self-shading and thylakoid 'transparency' (Berner et al. 1989). The smaller number of cells contributing to the chl-specific absorption coefficient at higher pigment/cell concentrations leads to the interesting observation that cell-specific absorption $\overline{\alpha A}$ did not vary as with increasing pigmentation or growth irradiance (data not shown). In this case the myriad effects of photoadaptive processes seem to lead to the maintenance of the cellular average absorption cross-section

Some chl-specific absorption values at $671 \mathrm{~nm}$ were higher than those commonly reported for chromophytic phytoplankton (Haardt \& Maske 1987, Sathyendranath et al. 1987, Bricaud et al. 1988). Calculations of the geometry of the spectrophotometer used (unpubl.) indicated that up to $10 \%$ of light scattered from a cell suspension during measurement may be unaccounted for. The absorption coefficient measured by the instrument can be described by the relationship:

$$
x=a+b(1-\varepsilon)
$$

(Sathyendranath et al. 1987), where a = absorption coefficient of the suspension; $b=$ scattering coefficient; and $\varepsilon=$ fraction of scattered light accepted by the instrument (i.e. 0.90 in the present study). Estimates of chl-specific scattering coefficient for Heterocapsa pygmaea based on cell size and pigmentation (Morel 1987. his Fig. 4) indicated that for the most weakly pigmented cells, measured absorption coefficient was $40 \%$ greater than the true absorption coefficient, while the most highly pigmented cells had measured absorption coefficient that were only $0.1 \%$ greater than the measured absorption coefficient. Thus, highly and moderately-pigmented cells can be assumed to have negligible scattering error.

Estimates of chl-specific absorption coefficients were made based on measurement of cellular pigmentation and dimensions, where the optical and molecular properties of the known pigment-protein complexes of dinoflagellates were combined with a simplified theoretical approach toward calculating the optical properties of particle suspensions. Reconstructed spectra of cultures grown at $<50 \mu$ Ein $\mathrm{m}^{-2} \mathrm{~s}^{-1}$ (Figs. 11a, b and 12a) corresponded most closely with

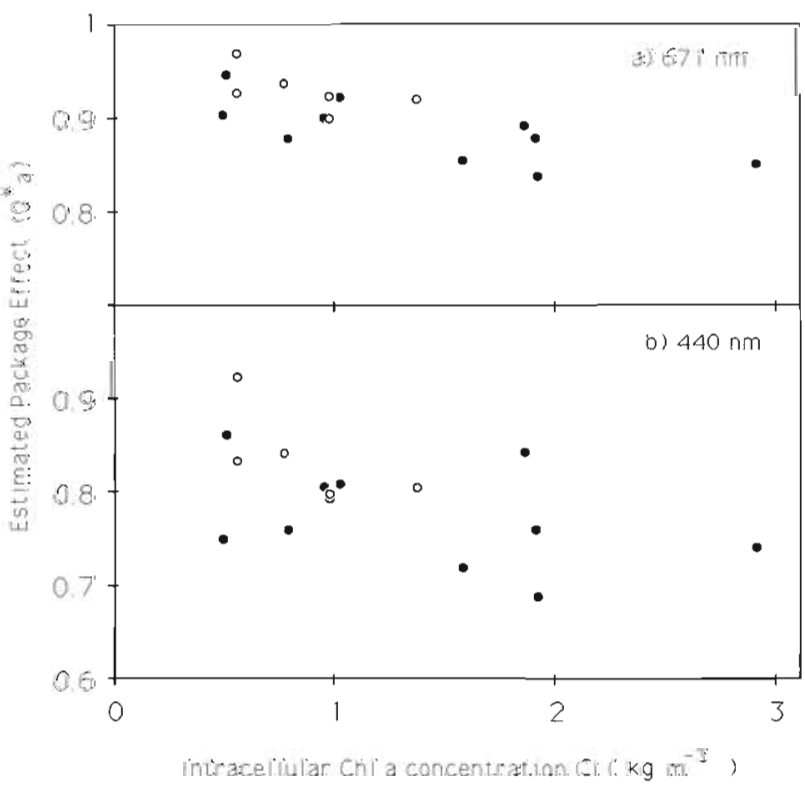

Fig. 10. Heterocapsa pygmaea. Relationship between cellular chl a concentration $\left(\mathrm{kg} \mathrm{m}^{-3}\right)$ and package effect estimated from measured spectra $\left(Q^{\circ}{ }^{\circ}\right.$ or $F$ ) at (a) $671 \mathrm{~nm}$ and (b) $440 \mathrm{~nm}$ for blue light $(\bullet)$ and green light $(0)$ grown cultures 
measured spectra, given that the package effect algorithm accounted for the majority of absorption overestimation in the pigment-only reconstructions. Remaining discrepancies between reconstructed and measured spectra may reflect (1) other 'packaging' effects such as self-shading due to thylakoid stacking (Berner et al. 1989) or effects of cell shape (Kirk 1976 , Bricaud et al. 1988); and (2) an underestimation of the in vivo absorbance properties of carotenoid-protein complexes, e.g. PCP and yellow xanthophylls, in the 450 to $550 \mathrm{~nm}$ range (Fig. 12b). At higher irradiances or much lower cell pigmentation (Figs. $11 \mathrm{c}$ and $12 \mathrm{c}$ ), the underestimation of measured absorbance by the model can be entirely accounted for by exaggeration of the measured spectra due to scattering loss. However, precise assessment of the fit between the reconstruction model and the measured spectra is not possible in these

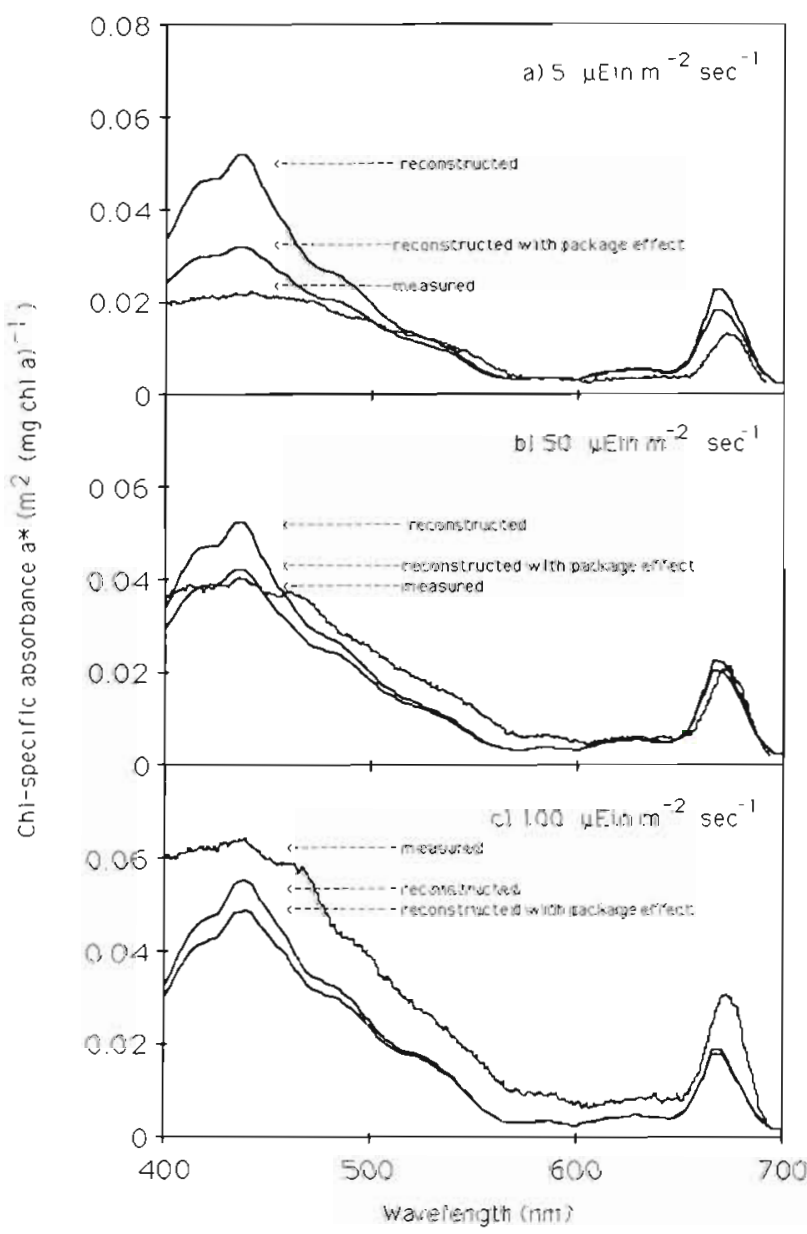

Fig. 11. Heterocapsa pygmaea. Chl-specific absorption spectra $\left[\mathrm{m}^{2}(\mathrm{mg} \mathrm{chl} \mathrm{a})^{-1}\right]$ for (a) $5 \mu \mathrm{Ein} \mathrm{m}^{-1} \mathrm{~s}^{-1}$, (b) $50 \mu \mathrm{Ein} \mathrm{m}^{-2}$ $\mathrm{s}^{-1}$, and (c) $100 \mu$ Ein $\mathrm{m}^{-2} \mathrm{~s}^{-1}$ blue light grown cells, where comparison is made directly between measured spectra, reconstructed spectra without consideration of the package effect, and reconstructed spectra with consideration of the package effect

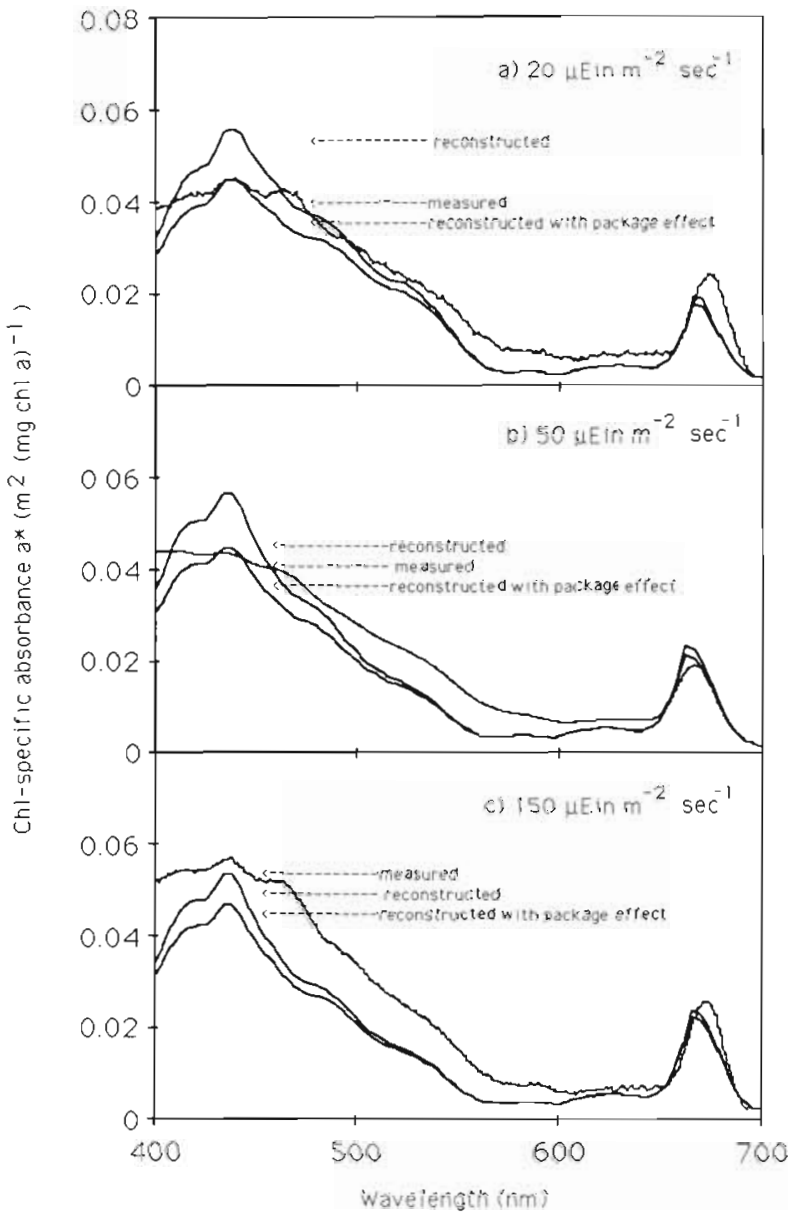

Fig. 12. Heterocapsa pygmaea. Chl-specific absorption spectra $\left[\mathrm{m}^{2}(\mathrm{mg} \mathrm{chl} \mathrm{a})^{-1}\right.$ | for (a) $20 \mu$ Ein $\mathrm{m}^{-2} \mathrm{~s}^{-1}$, (b) $95 \mu$ Ein m $^{-2} \mathrm{~s}^{-1}$, and

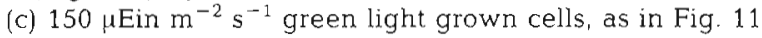

cases without exact measurement of scattering or elimination of scattering loss by the use of the integrating sphere technique (Haardt \& Maske 1987).

Accurate estimation of in situ phytoplankton absorption is important both as a basis for bio-optical modelling of primary production (Bidigare et al. 1987, Smith et al. 1989) and as predictors of apparent optical properties useful in remote sensing (Smith \& Baker 1978, Balch et al. 1989, Morel 1989). Our vanant of the spectral reconstruction model has the advantage of being based on molecular information unique to dinoflagellates, and thus has the potential to be applied to unialgal red tides. Unialgal dinoflagellate blooms can be treated as monodisperse systems, greatly simplifying package effect calculations, as average cell dimensions, volume, and cellular pigmentation can be accurately estimated. Ongoing research in this laboratory will couple optical data such as these with measurements of wavelength-dependent photosynthetic properties to complete a bio-optical model for dinoflagellate production. 
Acknowledgements. This work is dedicated to the memory of Beatrice M. Sweeney. Grants supporting research include ONR contract N00014-88-K-0060 to B.B.P. and E. L. Triplett, and NSF grant OCE88-00099 to B.B.P. We thank J. T O. Kirk and R. R. Bidigare for many helpful discussions and editorial comments; an anonymous reviewer provided valuable comments. Technical assistance by $\mathrm{H}$. A. Matlick and R. Petty is gratefully acknowledged.

\section{LITERATURE CITED}

Balch, W. M., Eppley, R. W., Abbott, M. R., Reid, F. M. H. (1989). Bias in satellite-derived pigment measurements due to coccolithophores and dinoflagellates. J. Plankton Res. $11 \cdot 575-581$

Berner, T., Dubinsky, Z., Wyman, K., Falkowski, P. (1989). Photoadaptation and the 'package effect' in Dunaliella tertiolecta (Chlorphyceae). J. Phycol. 25: 70-78

Bidigare, R. R., Smith, R. C., Baker, K. S., Marra, J. (1987). Optical production estimates from measurements of spectral irradiance and pigment concentration. Global Biogeochem. Cycles 1: 171-186

Bidigare, R. R., Schofield, O., Prézelin, B. B. (1989). Influence of zeaxanthin on quantum yield of photosynthesis of Synechococcus clone WH7803 (DC2). Mar. Ecol. Prog. Ser. 56: $177-188$

Boczar, B. A., Prézelin, B. B., Markwell, J., Thornber, J. P. (1980). A chl $c$-containing pigment-protein complex from the marine dinoflagellate, Glenodinium sp. FEBS Lett. 120: 243-247

Bricaud, A., Bedhomme, A.-L., Morel, A. (1988). Optical properties of diverse planktonic species: experimental results and theoretical interpretation. J. Plankton Res. 10: 851-873

Bricaud, A., Morel, A. (1983). Optical efficiency factors of some phytoplankton. Limnol. Oceanogr. 28: 816-832

Dubinsky, Z., Berman, T (1979). Seasonal changes in the spectral composition of downwelling irradiance in Lake Kinneret, Israel. Limnol. Oceanogr. 24: 652-663

Guillard, R. R. L. (1973). Division rates. In: Stein, J. R. (ed.) Handbook of phycological methods. Cambridge Univ. Press, Cambridge, p. 289-311

Guillard, R. R. L., Ryther, J. H. (1962). Studies of marine plantonic diatoms. I. Cyclotella nanna Hustedt and Detonula confervacea (Cleve) Gran. Can. J. Microbiol. 18: $229-239$

Haardt, H., Maske, H. (1987). Specific in vivo absorption coefficient of chlorophyll $a$ at $675 \mathrm{~nm}$. Limnol. Oceanogr. 32: $608-619$

Iturriaga, R., Mitchell, B. G., Kiefer, D. A. (1988). Microphotometric analysis of individual particle absorption spectra. Limnol. Oceanogr. 33: 128-135

Jeffrey, S. W. (1981). An improved thin-layer chromatographic technique for marine phytoplankton pigments. Limnol. Oceanogr. 26: 191-197

Kirk, J. T. O. (1975). A theoretical analysis of the contribution of algal cells to the attenuation of light within natural waters. I. General treatment of pigmented cells. New Phytol. 75 : 11-20

Kirk, J. T. O. (1976). A theoretical analysis of the contribution of algal cells to the attenuation of light within natural waters. III. cylindrical and spheroidal cells. New Phytol. 77: $341-358$

Kirk, J. T. O. (1983). Light and photosynthesis in aquatic ecosystems. Cambridge Univ. Press, Cambridge

Kovala, P. E., Larrance, J. D. (1966). Computation of phyto- plankton cell numbers, cell volume, cell surface and plasma volume per liter, from microscopical counts. Univ. of Washington Department of Oceanography Spec. Rep. No. 38, Ref. M66-41

Loeblich, A. R. III, Schmidt, R. J., Sherley, J. L. (1981). Scanning electron micrography of Heterocapsa pygmaea sp nov., and evidence for polyploidy as a speciation mechanism in dinoflagellates. J. Plankton Res. 3: 67-79

Mantoura, R. F. C., Llewellyn, C. A. (1983). The rapid determination of algal chlorophyll and carotenoid pigments and their breakdown products by reverse-phase high performance liquid chromatography. Analyt. Chim. Acta 151 297-314

McTavish, H., Picorel, P., Siebert, M. (1989). Stabilization of isolated photosystem II reaction center complex in the dark and in the light using polyethylene glycol and an oxygen scrubbing system. Plant Physiol. 89: 452-456

Morel, A. (1987). Chlorophyll-specific scattering coefficient of phytoplankton. A simplified theoretical approach. Deep Sea Res. 34: 1093-1105

Morel, A. (1989). Optical modeling of the upper ocean in relation to its biogenous matter content (case I waters). J. geophys. Res. 93(C9): 10749-10768

Morel, A., Bricaud, A. (1981). Theoretical results concerning light absorption in a discrete medium, and application to specific absorption of phytoplankton. Deep Sea Res. 28A $1375-1393$

Prézelin, B. B. (1976). The role of peridinin-chlorophyll aproteins in the photosynthetic light adaptation of the marine dinoflagellate, Glenodinium sp. Planta (Berl.) 130: 225-233

Prézelin, B. B. (1987). Photosynthetic physiology of dinoflagellates. In: Taylor, F. J. R. (ed.) The biology of dinoflagellates. Blackwell Scientific, Oxford p. 174-223

Prézelin, B. B., Alberte, R. S. (1978). Photosynthetic characteristics and organization of chlorophyl in marine dinoflagellates. Proc. nat. Acad. Sci. USA 75: 1801-1804

Prézelin, B. B., Boczar, B. A. (1981). Chlorophyll-protein complexes from the photosynthetic apparatus of dinoflagellates. In: Akoyunoglou, G. (ed.) Photosynthesis III: structure and function of the photosynthetic apparatus. Balaban International, Philadelphia, p. 417-425

Prézelin, B. B., Boczar, B. A. (1986). Molecular bases of cell absorption and fluorescence in phytoplankton: potential applications to studies in optical oceanography. In: Round F. T., Chapman, D. J. (eds.) Progress in phycological research, Vol. 4. Biopress Ltd. Bristol, p. 350-464

Prézelin, B. B., Ley, A. C., Haxo, F. T. (1976). Effect of growth irradiance on the photosynthetic action spectra of the marine dinoflagellate, Glenodinium sp. Planta (Berl.) 130 251-256

Roman, S. J., Govind, N. S., Triplett, E. L., Prézelin, B. B (1988). Light regulation of peridinin-chlorophyll a-protein (PCP) complexes in the dinoflagellate, Glenodinium $\mathrm{sp}$ Plant Physiol. 88: 594-599

Sathyendranath, S., Lazzara, L., Prieur, L. (1987). Variations in the spectral values of specific absorption of phytoplankton. Limnol. Oceanogr. 32: 403-415

Shibata, K. (1959). Spectrophotometry of translucent biological materials - opal glass transmission method. Meth biochem. Analysis 7: 77-109

Shibata, K., Benson, A. A., Calvin, M. (1954). The absorption spectra of suspensions of living microorganisms. Biochim. Biophys. Acta 15: 461-470

Smith, R. C., Baker, K. S. (1978). Optical classification of natural waters. Limnol. Oceanogr. 23: 260-267

Smith, R. C., Prézelin, B. B., Bidigare, R. R., Baker, K. S. (1989) 
Bio-optical modeling of primary production in coastal waters. Limnol. Oceanogr 34: 1526-1546

Song, P. S., Koka. P., Prézelin, B. B. and Haxo, F. T (1976). Molecular topology of the photosynthetic light-harvesting

This article was submitted to the editor complex, peridinin-chlorophyll-a protein, from marine dinoflagellates. Biochem. 15: 4422-4427

Taylor, F. J. R. (ed.) The biology of dinoflaggelates. Blackwell Sclentific, Oxford

Manuscript first received: November 6, 1989

Revised version accepted: February 2, 1990 